\title{
IMPACT OF DIABETIC RETINOPATHY SCREENING CAMPS AND WORKSHOPS ON PATIENTS AND HEALTH CARE PERSONNEL
}

\author{
M. Shiraz Ali' ${ }^{1}$ Rajiv Kumar Gupta², Marianus Deepak Lakra ${ }^{3}$, Sunil Kumar ${ }^{4}$, Hemlata Bharti 5
}

${ }^{1}$ Consultant Ophthalmologist, "Eye $n$ You", Advanced Center for Cataract \& Glaucoma Management, Ranchi.

${ }^{2}$ Associate Professor, Department of Ophthalmology, Regional Institute of Ophthalmology, Rajendra Institute of Medical Sciences, Bariatu, Ranchi.

${ }^{3}$ Associate Professor, Department of Ophthalmology, Regional Institute of Ophthalmology, Rajendra Institute of Medical Sciences, Bariatu, Ranchi.

${ }^{4}$ Associate Professor, Department of Ophthalmology, Regional Institute of Ophthalmology, Rajendra Institute of Medical Sciences, Bariatu, Ranchi.

${ }^{5}$ Senior Resident, Department of Ophthalmology, Regional Institute of Ophthalmology, Rajendra Institute of Medical Sciences, Bariatu, Ranchi.

\section{ABSTRACT}

\section{BACKGROUND}

The aim of this study is to know the level of awareness among patients, general physicians, para-ophthalmic personnel and ophthalmologists regarding diabetic retinopathy in tribal dominated state of Jharkhand, India.

\section{MATERIALS AND METHODS}

Screening camps and workshops with patients, general physicians, para-ophthalmic personnel and ophthalmologists were conducted in Ramgarh district of Jharkhand. Patients were counselled about complexities of diabetic retinopathy. Diabetics were counselled about importance of yearly examination of fundus. Leaflets containing information about diabetic retinopathy were distributed in workshops. Para-ophthalmic personnel and general physicians were trained in using direct ophthalmoscope to screen cases and prompt referral to higher centres. Ophthalmologists were updated in proper diagnosis and management of diabetic retinopathy. The patients, general physicians, para-ophthalmic personnel and ophthalmologists were also asked to respond to 3-point questionnaires.

\section{RESULTS}

A total of 110 diabetics, 4 general physicians, 12 para-ophthalmic personnel and 5 ophthalmologists participated in the 1 st camp whereas there were 123 diabetics, 2 general physicians, 12 para-ophthalmic personnel and 3 ophthalmologists in the $2^{\text {nd }}$ camp. The patients in the $2^{\text {nd }}$ camp performed much better as compared to the $1^{\text {st }}$ camp. The performance of para-ophthalmic personnel was slightly better in the $2^{\text {nd }}$ camp in comparison to the $1^{\text {st }}$ camp. The response of the general physicians and ophthalmologists were almost similar in both the camps.

\section{CONCLUSION}

At the end of 1 year, a perceptible change in knowledge, attitude and awareness was felt among patients, general physicians, paraophthalmic personnel and ophthalmologists.

\section{KEYWORDS}

Awareness, Diabetic Retinopathy, Eye Check-up.

HOW TO CITE THIS ARTICLE: Ali MS, Gupta RK, Lakra MD, et al. Impact of diabetic retinopathy screening camps and workshops on patients and health care personnel. J. Evolution Med. Dent. Sci. 2017;6(37):3019-3023, DOI: 10.14260/Jemds/2017/651

\section{BACKGROUND}

Diabetes mellitus, particularly type 2 , is a major public health concern worldwide. ${ }^{1}$ According to WHO, there will be an alarming increase in the population with diabetes mellitus type 2, both in the developed and developing countries over the next two decades. In the developed world, the estimated

Financial or Other, Competing Interest: None.

Submission 24-03-2017, Peer Review 25-04-2017,

Acceptance 01-05-2017, Published 08-05-2017.

Corresponding Author:

Dr. M. Shiraz Ali,

"Eye n You",

Advanced Center for Cataract \& Glaucoma Management,

$3^{\text {rd }}$ Floor, NILE Complex,

Old Hazaribag Road, Kantatoli,

Ranchi-834001,

Jharkhand, India.

E-mail: mshirazali786@gmail.com

DOI: $10.14260 /$ jemds $/ 2017 / 651$ increase is approximately $46 \%$ from 55 million in 2000 to 83 million in 2030; whereas among developing nations, the estimated increase is approximately $150 \%$, from 30 million in 2000 to 80 million in $2030 .^{1}$

The complications associated with diabetes are appalling. Retinopathy is the most common eye disease in diabetes and is caused by changes in the blood vessels of the retina.

It has increasingly become a major cause of blindness throughout the world in the age group of $20-60$ years. $^{2}$ It is estimated that globally about 15,000 to 39,000 people lose their sight because of diabetes. ${ }^{3}$

Due to the social disease burden and subsequently the economic implication as a result of the diabetic eye disease, a high level of awareness is needed to educate diabetic patients with regards to this debilitating complication. Previous research has shown that $63 \%$ of the rural diabetic population have not had an eye examination. ${ }^{4}$ Similarly, the nonresponse to the invitation to attend diabetic retinopathy screening camps was such that of 1076 people who were 
diagnosed as having diabetes in the diabetes detection screening camps, only 125 (11.6\%) attended the diabetic retinopathy screening camps, conducted just one week later. ${ }^{5}$

In a study of an urban general population in India where the prevalence of diabetic retinopathy was high, Dandona et $\mathrm{al}^{6}$ observed a low level (27\%) of awareness about this dreaded complication.

The present study was undertaken to assess the awareness level or knowledge of diabetes and diabetic retinopathy in a rural and semi-urban population as well as among general physicians, para-ophthalmic personnel and ophthalmologists and its association with their attitude and practice.

\section{MATERIALS AND METHODS}

This study was conducted according to the principles of the Helsinki Declaration on research involving human subjects. Our Institutional Ethics Committee approved the protocol for the study. Verbal informed consent was obtained from all subjects who participated in the study. Confidentiality was maintained.

The first diabetic retinopathy screening camp and workshop was conducted in the town of Ramgarh, in district Ramgarh, Jharkhand State on $12^{\text {th }}$ and $13^{\text {th }}$ March, 2014. Relevant strategy was used to create a targeted level of awareness of diabetes and diabetic retinopathy.

One month prior to the camp, leaflets, banners and posters containing information regarding diabetic retinopathy screening camp and workshop were distributed and displayed throughout the targeted district. All leaflets, banners and posters were in the local Hindi language. Announcements were also made over the loudspeakers among the local populace. These were again made in the local Hindi language. One day prior to the camp, information was also given through the local Hindi newspaper.

The volunteers helped in the dissemination of information by visiting primary health centres, community health centres, government hospitals, private hospitals, private nursing homes, private practitioners, paraophthalmic personnel and ophthalmologists active in the Ramgarh district. All primary care providers, general physicians, para-ophthalmic personnel and ophthalmologists were emphasised about the importance of attending the camp; in addition, they were asked to convince all diabetic patients under their care to attend the camp.

The participants for this study included diabetic patients, general physicians, para-ophthalmic personnel and ophthalmologists. A team of ophthalmologists and ophthalmic assistants constituted the investigators.

Investigators conducted face-to-face interviews focused on assessing current levels of awareness regarding diabetic retinopathy with participants identified for the study. We used semi-structured questionnaires for the interviews. A guideline for the preparation of the questionnaires was obtained after a detailed search in the literature on previous published reports of knowledge and awareness of diabetic retinopathy for a study population. ${ }^{7}$

Before commencing the test, the questionnaires were pre-tested in a sample of diabetic patients attending our institute's eye outdoor department, physicians, paraophthalmic personnel and ophthalmologists of our institute. Based upon the responses given, necessary modifications were made to enhance comprehension. All the questions were in the format of "Yes" or "No"; and all questionnaires were administered in the local Hindi language.

The patients were asked to respond to a 3-point questionnaire before their eye examination was done. The general physicians, para-ophthalmic personnel and ophthalmologists were also asked to respond to 3-point questionnaires.

A total of 293 patients attended the camp. These patients were screened based on previous medical history alone and only known diagnosed cases of diabetes mellitus type 2 were enrolled into the study; which were 110 in number.

So, a total of 110 diabetic patients were enrolled into the study. In addition, 4 general physicians, 12 para-ophthalmic personnel and 5 ophthalmologists were also enrolled into the study and also participated in the workshop.

Detailed demographics, education status, and duration of diabetes mellitus in patients were noted. All diabetics were explained about the complexities of diabetic retinopathy and emphasised about the importance of regular, yearly examination of the fundus. Leaflets containing information about diabetic retinopathy were also distributed among them. After the interview, all diabetic patients underwent fundus examination.

The general physicians were also explained about the complexities of diabetic retinopathy and emphasised about the importance of regular, yearly examination of the fundus. The general physicians were trained how to use a direct ophthalmoscope in dilated pupils to screen diabetic retinopathy cases. Photographs of normal fundus and diabetic fundus were shown to them on laptops. They were told that any deviation from normal fundus required a prompt ophthalmologist referral.

All para-ophthalmic personnel were counselled to get random blood sugar test done on all patients (Irrespective of diabetic status) on a routine basis. They were also trained in direct ophthalmoscopy. Photographs of normal fundus and diabetic fundus were also shown to them on laptops. They were told that any deviation from normal fundus required a prompt ophthalmologist referral.

The ophthalmologists were updated regarding the various treatment modalities for diabetic retinopathy. ETDRS classification was explained to them by means of photographs on the laptops and told about the various treatment strategies that could be delivered at each stage of the disease.

After about one year, a diabetic screening camp and workshop was once again organised in the same township of Ramgarh, in district of Ramgarh, Jharkhand State on $18^{\text {th }}$ and 19th March, 2015.

At the $2^{\text {nd }}$ camp, a different set of diabetic patients turned up. About 40 patients who had earlier attended the $1^{\text {st }}$ camp also turned up. A total of 123 known diagnosed cases of diabetes mellitus type 2 (including the previous 40 patients) were enrolled into the study. From the $1^{\text {st }}$ camp, only 2 general physicians, all 12 para-ophthalmic personnel and 3 ophthalmologists participated in the $2^{\text {nd }}$ camp. All participants were asked to respond to the same set of 3-point questionnaires.

All patients at both camps underwent random blood sugar test by glucometer. A value of $>180 \mathrm{mg} / \mathrm{dL}$ was taken as the cut-off value for newly diagnosed diabetes mellitus. A total of 19 patients at the $1^{\text {st }}$ camp and 17 patients at the $2^{\text {nd }}$ 
camp had a level of $>180 \mathrm{mg} / \mathrm{dL}$. These newly diagnosed diabetics were not enrolled into the study but underwent thorough fundus examination and counselling regarding diabetic retinopathy.

\section{Statistical Analysis}

The collected data were analysed in SPSS (Version 20).

\section{RESULTS}

A total of 110 diabetic patients, 4 general physicians, 12 paraophthalmic personnel and 5 ophthalmologists participated in the $1^{\text {st }}$ camp. In the $2^{\text {nd }}$ camp, 123 diabetic patients, 2 general physicians, 12 para-ophthalmic personnel and 3 ophthalmologists were participants. (Table 1).

\section{Patients}

The demographic profile, education status, and duration of diabetes mellitus of patients in $1^{\text {st }}$ and $2^{\text {nd }}$ camps were almost similar.

The mean age of patients in $1^{\text {st }}$ camp was $57.32 \pm 10.573$ years and $57.70 \pm 9.973$ years in $2^{\text {nd }}$ camp. Majority of the patients in both camps were in the age group of $50-59$ years. (Table 2).

Males exceeded females in both camps. (Table 3).

In both camps, majority of the patients were followers of Hinduism, followed by Islam and Christianity. (Table 4).

In both camps, literates were more than illiterates. (Table 5).

Among the diabetics, about $33.6 \%$ (37 patients) in $1^{\text {st }}$ camp and $56.9 \%$ (70 patients) in $2^{\text {nd }}$ camp had signs of retinopathy. A high percentage of patients in the $2^{\text {nd }}$ camp had retinopathy changes. This may be because this set of patients also included many patients from the $1^{\text {st }}$ camp who had retinopathy changes. In both camps, the highest percentage of diabetic retinopathy changes were seen in patients with duration of diabetes more than 10 years. (Table 6).

\section{Awareness in Patients (Table 7)}

In comparison to the $1^{\text {st }}$ camp, patients who attended the $2^{\text {nd }}$ camp were more aware that diabetes could affect the eye $(p=0.000)$. Also, majority of their physicians had advised them to get an eye check-up ( $p=0.000)$. Patients of $2^{\text {nd }}$ camp were also more aware of treatment for diabetic retinopathy $(\mathrm{p}=0.000)$

However, we should interpret this finding with caution because the second sample of patients also included the 40 patients who had already attended the $1^{\text {st }}$ camp.

But what was alarming was that still $23.6 \%$ of general physicians were not advising their diabetic patients a regular yearly eye check-up.

\section{Response of General Physicians (Table 8)}

Only 2 general physicians turned up in the $2^{\text {nd }}$ camp from the original group of 4 who had attended the $1^{\text {st }}$ camp. The other 2 were unavailable due to personal reasons or were out of station.

In the $1^{\text {st }}$ camp, $50 \%$ of physicians were not advising their diabetic patients to undergo eye examination because they felt that when blood sugar levels were well controlled, there was no need for any eye examination. In the $2^{\text {nd }}$ camp, almost all (100 \%) physicians had started advising their patients for eye check-up.

$25 \%$ of physicians in $1^{\text {st }}$ camp and $50 \%$ in $2^{\text {nd }}$ camp knew how to use a direct ophthalmoscope. In the $2^{\text {nd }}$ camp, one physician was still not comfortable in using a direct ophthalmoscope; mainly because of his busy practice, he did not make effort to do so though he was offered training in the $1^{\text {st }}$ camp.

At the end of both camps, all physicians (100\%) were able to do direct ophthalmoscopy in a correct way.

Few general physicians $\left(25 \%\right.$ in $1^{\text {st }}$ camp and $0 \%$ in $2^{\text {nd }}$ camp) had educational material in any form.

\section{Response of Para-ophthalmic Personnel (Table 9)}

At the $1^{\text {st }}$ camp, only $25 \%$ of the para-ophthalmic personnel had been evaluating the fundus of diabetic patients either because they were trained to do so or due to availability of direct ophthalmoscope at their centres. The remaining 75\% knew about direct ophthalmoscope but had never used them because either they were not trained or due to unavailability of the instrument at their centres. At the $2^{\text {nd }}$ camp, it was found that still only $33.3 \%$ of the para-ophthalmic personnel had been doing direct ophthalmoscopy. The remaining $66.7 \%$ of them were not using direct ophthalmoscope because of unavailability of the instrument at their centres.

Majority of para-ophthalmic personnel $\left(83.3 \%\right.$ in $1^{\text {st }}$ camp and $75 \%$ in $2^{\text {nd }}$ camp) were not routinely performing blood sugar test on patients; largely because of unavailability of test strips.

Only $58.3 \%$ of para-ophthalmic personnel in $1^{\text {st }}$ camp were referring diabetics to ophthalmologists only because they were unable to do direct ophthalmoscopy. The remaining $41.7 \%$ felt that when blood sugar levels were well controlled and visual acuity of patients was satisfactory $(\geq 6 / 12)$, there was no need for any eye examination. At the $2^{\text {nd }}$ camp, majority (83.3\%) of para-ophthalmic personnel had started referring the diabetic patients to the ophthalmologists irrespective of blood sugar levels and visual acuity. The remaining $16.7 \%$ were not referring the patients because they still felt that unless visual acuity deteriorated, there was no need for any referral.

At the end of both camps, all para-ophthalmic personnel (100\%) were able to do direct ophthalmoscopy in a correct way.

\section{Response of Ophthalmologists (Table 10)}

Only 3 ophthalmologists turned up in the $2^{\text {nd }}$ camp from the original group of 5 who had attended the $1^{\text {st }}$ camp. The other 2 were unavailable due to personal reasons or were out of station.

It was encouraging to know that nearly all (100\%) ophthalmologists at both camps were aware of the various treatment modalities available for diabetic retinopathy.

On the other hand, it was unfortunate that nearly all (100\%) ophthalmologists at both camps were not using ETDRS classification. They all preferred to classify diabetic retinopathy simply into non-proliferative diabetic retinopathy and proliferative diabetic retinopathy. This may be because of time constraints.

About $60 \%$ of ophthalmologists in $1^{\text {st }}$ camp and $66.7 \%$ in $2^{\text {nd }}$ camp were keen and showed genuine interest in training 
in medical retina. The remaining ophthalmologists who lacked interest were, perhaps, senior citizens and were probably happy and satisfied in practising general ophthalmology only.

\begin{tabular}{|c|c|c|}
\hline Participants & $\begin{array}{c}1^{\text {st }} \text { Camp } \\
\text { (n) }\end{array}$ & $\begin{array}{c}\text { 2 }^{\text {nd }} \text { Camp } \\
\text { (n) }\end{array}$ \\
\hline Diabetic Patients & 110 & 123 \\
\hline General Physicians & 4 & 2 \\
\hline Para-ophthalmic Personnel & 12 & 12 \\
\hline Ophthalmologists & 5 & 3 \\
\hline \multicolumn{2}{|c|}{ Table 1. Distribution of Participants } \\
\hline
\end{tabular}

\begin{tabular}{|c|c|c|c|c|}
\hline \multirow{2}{*}{$\begin{array}{c}\text { Age Range } \\
\text { (Years) }\end{array}$} & \multicolumn{2}{|c|}{$\mathbf{1}^{\text {st }}$ Camp } & \multicolumn{2}{c|}{ 2 $^{\text {nd }}$ Camp } \\
\cline { 2 - 5 } & $\mathbf{n}$ & $\mathbf{\%}$ & $\mathbf{N}$ & $\mathbf{\%}$ \\
\hline $30-39$ & 8 & 7.3 & 8 & 6.5 \\
\hline $40-49$ & 15 & 13.6 & 16 & 13.0 \\
\hline $50-59$ & 43 & 39.1 & 48 & 39.0 \\
\hline $60-69$ & 33 & 30.0 & 37 & 30.1 \\
\hline$\geq 70$ & 11 & 10.0 & 14 & 11.4 \\
\hline
\end{tabular}

\begin{tabular}{|c|c|c|c|c|}
\hline \multirow{2}{*}{ Sex } & \multicolumn{2}{|c|}{$\mathbf{1}^{\text {st }}$ Camp } & \multicolumn{2}{c|}{ 2nd Camp $^{\text {nd }}$} \\
\cline { 2 - 5 } & $\mathbf{n}$ & $\mathbf{\%}$ & $\mathbf{n}$ & $\mathbf{\%}$ \\
\hline Males & 68 & 61.8 & 77 & 62.6 \\
\hline Females & 42 & 38.2 & 46 & 37.4 \\
\hline Table 3. Sex Distribution of Patients \\
\hline
\end{tabular}

\begin{tabular}{|c|c|c|c|c|}
\hline \multirow{2}{*}{ Religion } & \multicolumn{2}{|c|}{$\mathbf{1}^{\text {st }}$ Camp } & \multicolumn{2}{c|}{ 2 $^{\text {nd }}$ Camp } \\
\cline { 2 - 5 } & $\mathbf{n}$ & $\mathbf{\%}$ & $\mathbf{n}$ & $\mathbf{\%}$ \\
\hline Hinduism & 80 & 72.7 & 93 & 75.6 \\
\hline Islam & 16 & 14.5 & 16 & 13.0 \\
\hline Christianity & 8 & 7.3 & 10 & 8.1 \\
\hline Others & 6 & 5.5 & 4 & 3.3 \\
\hline Table 4. Religion Distribution of Patients \\
\hline
\end{tabular}

\begin{tabular}{|c|c|c|c|c|}
\hline \multirow{2}{*}{ Education } & \multicolumn{2}{|c|}{ 1st $^{\text {Camp }}$} & \multicolumn{2}{c|}{ 2 $^{\text {nd }}$ Camp } \\
\cline { 2 - 5 } & $\mathbf{n}$ & $\mathbf{\%}$ & $\mathbf{n}$ & $\mathbf{\%}$ \\
\hline Illiterate & 46 & 41.8 & 53 & 43.1 \\
\hline Literate & 64 & 58.2 & 70 & 56.9 \\
\hline Table 5. Education Level of Patients \\
\hline
\end{tabular}

\begin{tabular}{|c|c|c|c|c|}
\hline \multirow{3}{*}{$\begin{array}{c}\text { Duration } \\
\text { of Diabetes }\end{array}$} & \multirow{2}{*}{\multicolumn{2}{|c|}{$\begin{array}{c}\text { 1 }{ }^{\text {st }} \text { Camp } \\
\text { Diabetic } \\
\text { Retinopathy } \\
\text { Present }\end{array}$}} & \multirow{2}{*}{\multicolumn{2}{|c|}{$\begin{array}{c}\text { 2 }^{\text {nd }} \text { Camp } \\
\text { Diabetic } \\
\text { Retinopathy } \\
\text { Present }\end{array}$}} \\
\hline & & & & \\
\hline & $\mathbf{n}$ & $\%$ & $\mathbf{n}$ & $\%$ \\
\hline$<5$ Years & 2 & 5.4 & 4 & 5.7 \\
\hline 5 - 10 Years & 7 & 18.9 & 8 & 11.4 \\
\hline$>10$ Years & 28 & 75.7 & 58 & 82.9 \\
\hline
\end{tabular}

Table 6. Association of Duration of Diabetes Mellitus Type 2 and Diabetic Retinopathy

\begin{tabular}{|c|c|c|c|c|c|c|}
\hline & \multirow[b]{2}{*}{ Questions } & \multicolumn{2}{|c|}{$1^{\text {st }}$ Camp } & \multicolumn{2}{|c|}{$2^{\text {nd }}$ Camp } & \multirow[b]{2}{*}{$\begin{array}{c}\text { Chi Square } \\
\text { p value }\end{array}$} \\
\hline & & \begin{tabular}{|c|} 
Yes \\
N (\%)
\end{tabular} & \begin{tabular}{|c|} 
No \\
N (\%)
\end{tabular} & $\begin{array}{c}\text { Yes } \\
\text { N (\%) }\end{array}$ & \begin{tabular}{|c|} 
No \\
N (\%)
\end{tabular} & \\
\hline 1. & $\begin{array}{l}\text { Are you aware } \\
\text { that diabetes } \\
\text { can affect the }\end{array}$ & $\begin{array}{c}30 \\
(27.3)\end{array}$ & $\begin{array}{c}80 \\
(72.7)\end{array}$ & $\begin{array}{c}65 \\
(52.8)\end{array}$ & $\mid \begin{array}{c}58 \\
(47.2)\end{array}$ & $\begin{array}{c}\text { Chi Square } \\
=15.726 \\
p=0.000\end{array}$ \\
\hline
\end{tabular}

\begin{tabular}{|c|c|c|c|c|c|c|}
\hline & eye? & & & & & \\
\hline 2. & $\begin{array}{c}\text { Did physicians } \\
\text { advise eye } \\
\text { check-up? }\end{array}$ & $\begin{array}{c}45 \\
(40.9)\end{array}$ & $\begin{array}{c}65 \\
(59.1)\end{array}$ & $\begin{array}{c}94 \\
(76.4)\end{array}$ & $\begin{array}{c}29 \\
(23.6)\end{array}$ & $\begin{array}{c}\text { Chi Square } \\
=30.430 \\
\mathrm{p}=0.000\end{array}$ \\
\hline 3. & $\begin{array}{c}\text { Are you aware } \\
\text { of treatment for } \\
\text { diabetic } \\
\text { retinopathy? }\end{array}$ & $\begin{array}{c}25 \\
(22.7)\end{array}$ & $\begin{array}{c}85 \\
(77.3)\end{array}$ & $\begin{array}{c}57 \\
(46.3)\end{array}$ & $\begin{array}{c}66 \\
(53.7)\end{array}$ & $\begin{array}{c}\text { Chi Square } \\
=14.197 \\
\mathrm{p}=0.000\end{array}$ \\
\hline
\end{tabular}

Table 7. Awareness of Diabetic Retinopathy in Patients

\begin{tabular}{|c|c|c|c|c|c|c|}
\hline & \multirow[b]{2}{*}{ Questions } & \multicolumn{2}{|c|}{$1^{\text {st }}$ Camp } & \multicolumn{2}{|c|}{$2^{\text {nd }}$ Camp } & \multirow{2}{*}{$\begin{array}{c}\text { Chi } \\
\text { Square } \\
\text { p value } \\
\end{array}$} \\
\hline & & $\begin{array}{c}\text { Yes } \\
\text { N (\%) }\end{array}$ & $\begin{array}{c}\text { No } \\
\text { N (\%) }\end{array}$ & \begin{tabular}{|c|} 
Yes \\
N (\%)
\end{tabular} & $\begin{array}{c}\text { No } \\
\text { N (\%) }\end{array}$ & \\
\hline 1. & $\begin{array}{c}\text { Do you advise } \\
\text { diabetics to } \\
\text { undergo eye } \\
\text { check-up? }\end{array}$ & $\begin{array}{c}2 \\
(50)\end{array}$ & $\begin{array}{c}2 \\
(50)\end{array}$ & $\begin{array}{c}2 \\
(100)\end{array}$ & $\begin{array}{c}0 \\
(0)\end{array}$ & $\begin{array}{c}\text { Chi Square } \\
=1.500 \\
p=0.221\end{array}$ \\
\hline 2. & $\begin{array}{l}\text { Do you know how } \\
\text { to use a direct } \\
\text { ophthalmoscope? }\end{array}$ & $\begin{array}{c}1 \\
(25)\end{array}$ & $\begin{array}{c}3 \\
(75)\end{array}$ & $\begin{array}{c}1 \\
(50)\end{array}$ & $\begin{array}{c}1 \\
(50)\end{array}$ & $\begin{array}{c}\text { Chi Square } \\
=3.000 \\
p=0.08\end{array}$ \\
\hline 3. & $\begin{array}{l}\text { Do you have any } \\
\text { educational } \\
\text { material related } \\
\text { to diabetes } \\
\text { (printed } \\
\text { materials, flip - } \\
\text { charts, audio } \\
\text { cassettes)? }\end{array}$ & $\begin{array}{c}1 \\
(25)\end{array}$ & $\begin{array}{c}3 \\
(75)\end{array}$ & $\begin{array}{c}0 \\
(0)\end{array}$ & $\begin{array}{c}2 \\
(100)\end{array}$ & $\begin{array}{c}\text { Chi Square } \\
=0.600 \\
p=0.439\end{array}$ \\
\hline \multicolumn{7}{|c|}{ Table 8. Response of General Physicians } \\
\hline
\end{tabular}

\begin{tabular}{|c|c|c|c|c|c|c|}
\hline & \multirow[b]{2}{*}{ Questions } & \multicolumn{2}{|c|}{$1^{\text {st }}$ Camp } & \multicolumn{2}{|c|}{$2^{\text {nd }}$ Camp } & \multirow[b]{2}{*}{$\begin{array}{c}\text { Chi Square } \\
\text { p value }\end{array}$} \\
\hline & & $\begin{array}{c}\text { Yes } \\
\text { N (\%) }\end{array}$ & $\begin{array}{c}\text { No } \\
\text { N (\%) }\end{array}$ & $\begin{array}{c}\text { Yes } \\
\text { N (\%) }\end{array}$ & $\begin{array}{c}\text { No } \\
\text { N (\%) }\end{array}$ & \\
\hline 1. & $\begin{array}{l}\text { Do you evaluate } \\
\text { the fundus of } \\
\text { diabetic patients? }\end{array}$ & $\begin{array}{c}3 \\
(25)\end{array}$ & $\begin{array}{c}9 \\
(75)\end{array}$ & $\begin{array}{c}4 \\
(33.3)\end{array}$ & $\begin{array}{c}8 \\
(66.7)\end{array}$ & $\begin{array}{c}\text { Chi Square } \\
=0.202 \\
p=0.653\end{array}$ \\
\hline 2. & $\begin{array}{l}\text { Do you perform } \\
\text { blood sugar test on } \\
\text { all patients? }\end{array}$ & $\begin{array}{c}2 \\
(16.7)\end{array}$ & $\begin{array}{c}10 \\
(83.3)\end{array}$ & $\begin{array}{c}3 \\
(25)\end{array}$ & $\begin{array}{c}9 \\
(75)\end{array}$ & $\begin{array}{c}\text { Chi Square } \\
=0.253 \\
p=0.615\end{array}$ \\
\hline 3. & $\begin{array}{c}\text { Do you refer } \\
\text { diabetic patients } \\
\text { to } \\
\text { ophthalmologists? }\end{array}$ & $\begin{array}{c}7 \\
(58.3)\end{array}$ & $\begin{array}{c}5 \\
(41.7)\end{array}$ & $\begin{array}{c}10 \\
(83.3)\end{array}$ & $\begin{array}{c}2 \\
(16.7)\end{array}$ & $\begin{array}{c}\text { Chi Square } \\
=1.815 \\
p=0.178\end{array}$ \\
\hline
\end{tabular}

Table 9. Response of Para-ophthalmic Personnel

\begin{tabular}{|c|c|c|c|c|c|c|}
\hline & \multirow[b]{2}{*}{ Questions } & \multicolumn{2}{|c|}{$1^{\text {st }}$ Camp } & \multicolumn{2}{|c|}{$2^{\text {nd }}$ Camp } & \multirow{2}{*}{\begin{tabular}{|c} 
Chi \\
Square \\
p value
\end{tabular}} \\
\hline & & $\begin{array}{c}\text { Yes } \\
\text { N (\%) }\end{array}$ & $\begin{array}{c}\text { No } \\
\text { N (\%) }\end{array}$ & $\begin{array}{c}\text { Yes } \\
\text { N (\%) }\end{array}$ & $\begin{array}{c}\text { No } \\
\text { N (\%) }\end{array}$ & \\
\hline 1. & $\begin{array}{c}\text { Are you aware } \\
\text { of various } \\
\text { treatment } \\
\text { modalities } \\
\text { available for } \\
\text { diabetic } \\
\text { retinopathy? }\end{array}$ & $\begin{array}{c}5 \\
(100)\end{array}$ & $\begin{array}{c}0 \\
(0)\end{array}$ & $\begin{array}{c}3 \\
(100)\end{array}$ & $\begin{array}{c}0 \\
(0)\end{array}$ & \\
\hline 2. & $\begin{array}{c}\text { Do you use } \\
\text { ETDRS } \\
\text { classification? }\end{array}$ & $\begin{array}{c}0 \\
(0)\end{array}$ & $\begin{array}{c}5 \\
(100)\end{array}$ & $\begin{array}{c}0 \\
(0)\end{array}$ & $\begin{array}{c}3 \\
(100)\end{array}$ & \\
\hline 3. & $\begin{array}{c}\text { Are you } \\
\text { interested in } \\
\text { training } \\
\text { in medical } \\
\text { retina? }\end{array}$ & $\begin{array}{c}3 \\
(60)\end{array}$ & $\begin{array}{c}2 \\
(40)\end{array}$ & $\begin{array}{c}2 \\
(66.7)\end{array}$ & $\begin{array}{c}1 \\
(33.3)\end{array}$ & $\begin{array}{c}\text { Chi } \\
\text { Square } \\
=0.036 \\
p= \\
0.850\end{array}$ \\
\hline & Table 1 & & & & qists & \\
\hline
\end{tabular}




\section{DISCUSSION}

In India, a steady increase in the number of diabetic patients is a growing concern. There is an urgent need to increase awareness and knowledge of diabetes and its complications. Awareness creation in a community is one of the first steps in any programme aimed at reducing diabetic retinopathy ${ }^{6}$

As the illiterates coming from low socio-economic group form a major portion of our society, media (newspaper, television) plays a very minimal role in educating people. They have no access to such educational materials. So, a group approach is required. Group lectures, counselling sessions, awareness camps and workshops will be ideal.

Namperulasamy $\mathrm{P}$ and co-workers ${ }^{8}$ in a study done in the developing country found $29 \%$ of subjects unaware of diabetic retinopathy similar to the figures $\left(27 \%, 1^{\text {st }}\right.$ camp) obtained in our study. However, a study done in Singapore, ${ }^{9} \mathrm{a}$ developed country showed an awareness rate of $70-80 \%$. This state of decreased awareness of diabetic retinopathy in developing countries demands for many more health programmes for educating the public.

It is not uncommon to see a diabetic in advanced stages of retinopathy in a developing country because of irregular follow-up examination and late diagnosis of diabetes. Identifying and treating high-risk persons before severe vision loss can help to reduce blindness associated with diabetic retinopathy. ${ }^{10}$

Currently, leave alone diabetics, the general population, ${ }^{11}$ are not made aware of the ocular complications of diabetes and the need of regular yearly eye examination.

General physicians play a very important role in advising diabetics as they are the first ones to treat them. ${ }^{12}$ In our study, only $40.9 \%$ of diabetics were advised for eye check-up by their physicians. This is in contrast to the study by Rajani Kadri ${ }^{13}$ who found that $66 \%$ of the patients had been advised for eye check-up by physicians. This may reflect the small amount of time physicians can devote to discussion of diabetic complications with patients in a developing country with a low doctor-to-patient ratio like ours. Despite these challenges, the primary care physicians will continue to be the major resource persons for their diabetic patients who can help by referring them for ophthalmic evaluation in a timely manner.

Data from our study suggests that a lot of effort is required to increase awareness regarding diabetic retinopathy in this population and to transform this increased awareness to actual utilisation of services.

Our study also showed that it is not only the community who should be aware of diabetic complications but also general physicians and para-ophthalmic personnel.

In our study, at the end of one year, a perceptible change in knowledge, attitude and awareness was felt among patients, general physicians, para-ophthalmic personnel and ophthalmologists. But still, we have a long way to go in translating these numbers into meaningful numbers.

\section{Limitations}

Although the study had reached its aims, there were some unavoidable limitations. Firstly, the study was conducted only on a small size of population and therefore, to generalise the results for larger groups, the study should have involved more participants at different levels (patients, general physicians, para-ophthalmic personnel and ophthalmologists). Secondly, very minimal parameters were included in the questionnaires as against the other studies. Thirdly, the participants enrolled were consecutive cases which could introduce recruitment bias. Lastly, some respondents ( 2 general physicians and 2 ophthalmologists) did not give information because of their busy work schedule.

\section{CONCLUSION}

There is an urgent need for health education in order to increase the level of awareness about diabetic retinopathy in developing countries. Increasing the awareness will lead to an increase in understanding and acceptance of the importance of routine regular eye examination for early detection and treatment, thereby decreasing visual impairment.

\section{REFERENCES}

[1] Wild S, Roglic G, Green A, et al. Global prevalence of diabetes: estimates for the year 2000 and projections for 2030. Diabetes Care 2004;27(5):1047-53.

[2] Thylefors B, Negrel AD, Pararajasegaram R, et al. Global data on blindness. Bull World Health Organ 1995;73(1):115-21.

[3] The second national health and morbidity survey 2007. Diabetes mellitus among adults aged 30 years and above. Institute of Public Health (IPH), ministry of health, Malaysia 2008.

[4] Padmaja KR, Rajiv R, Pradeep GP, et al. Use of eye care services by people with diabetes - South India experience. British Journal of Ophthalmology 2005. Available: http://bjo.bmj.com/cgi/eletter/82/4/410.

[5] Agarwal S, Mahajan S, Rani PK, et al. How high is the non-response rate of patients referred for eye examination from diabetic screening camps? Ophthalmic Epidemiology 2005;12(6):393-4.

[6] Dandona R, Dandona L, John RK, et al. Awareness of eye diseases in an urban population in southern India. Bulletin of World Health Organization 2001;79(2):96102.

[7] Rani PK, Raman R, Subramani S, et al. Knowledge of diabetes and diabetic retinopathy among rural populations in India and the influence of knowledge of diabetic retinopathy on attitude and practice. Rural and Remote Health 2008;8(3):838.

[8] Namperumalsamy P, Kim R, Kaliaperumal K, et al. A pilot study on awareness of diabetic retinopathy among non-medical persons in South India. The challenge for eye care programmes in the region. Indian J Ophthalmol 2004;52(3):247-51.

[9] Wee HL, Ho HK, Li SC. Public awareness of diabetes mellitus in Singapore. Singapore Med J 2002;43(3):128-34.

[10] Verma L, Elankumaran P, Prakash G, et al. Awareness of diabetic retinopathy among diabetics. Indian J Ophthalmol 2002;50(4):355.

[11] Jain S, Preetha K, Jain SC, et al. Diabetic retinopathy: a preventable scourge. J Indian Med Assoc 2008;106(5):303-6.

[12] Bhattacharjee S. Diabetic retinopathy: need for awareness amongst physicians. J Indian Med Assoc 2002;100(3):153-4.

[13] Rajani K. Awareness of diabetic and hypertensive eye disease in public. Int J Biol Med Res 2011;2(2):533-5. 